\title{
İş-Aile Çatışması, Yabancılaşma ve Psikolojik Belirtiler: Lojistik İşletmesi Çalışanları Üzerine Bir Araştırma
}

\author{
Meltem Akca a,b
}

\section{Özet}

$\mathrm{Bu}$ araştırmanın amacı iş-aile çatışmasının işe yabancılaşma üzerinde etkili olup olmadığını ortaya çıkarmak ve bu etkileşimde psikolojik belirtilerin rolünü belirlemektir. Bu kapsamda, literatür taraması yapılarak kavramsal çerçeve ve araştırma modeli oluşturulmuştur.Araştırmanın evreni, Türkiye' de üç şubede hizmet veren bir lojistik işletmesinin çalışanlarından meydana gelmektedir. Soru formları kolayda örnekleme yöntemi ile katılımcılara dağıtılmış ve elde edilen veriler üzerinde parametrik analizler uygulanmıştır. Araştırma sonucunda iş-aile çatışmasının işe yabancılaşmanın yordayıcısı olduğu saptanmıştır. Ayrıca psikolojik belirtilerin iş-aile çatışmasının işe yabancılaşma üzerindeki etkisinde kısmi aracı role sahip olduğu ortaya çıkarılmıştır.
Anahtar Kelimeler

İş-Aile Çatışması

Yabancılaşma

Psikolojik Belirtiler

Makale Hakkında

Geliş Tarihi: 01.11.2019

Kabul Tarihi: 10.06.2020

Doi: $10.18026 /$ cbayarsos.641612

\section{Work-Family Conflict, Alienation and Psychological Symptoms: A Research on Logistics Business Employees}

\begin{abstract}
The aim of this study is to determine whether work-family conflict is effective on alienation and to determine the role of psychological symptoms in this interaction. In this context, accordance with literature review the conceptual framework and research model were effectuated. Research population is comprised of logistics company's employees that serves in three departments in Turkey. The questionnaires were distributed to the participants by convenience sampling method and parametric analyzes were applied on the obtained data. As a result of the study, it was found that work-family conflict is the predictor of work alienation. It was also revealed out that psychological symptoms also have a partial mediating role in the effect of work-family conflict on work alienation.
\end{abstract}

Keywords

\begin{tabular}{r} 
Work-Life Conflict \\
Alienation \\
Psychological Symptoms \\
About Article \\
\hline Received: 01.11 .2019 \\
Accepted: 10.06 .2020 \\
Doi: $10.18026 /$ cbayarsos.641612
\end{tabular}

a İletişim Yazarı: meltem.akca@alanya.edu.tr

b Dr. Öğretim Üyesi, Alanya Alâaddin Keykubat Üniversitesi Gazipaşa Havacılık ve Uzay Bilimleri Fakültesi, Gazipaşa/Antalya, ORCID No: 00000001-5544-5929 


\section{Giriş}

Örgütsel davranış, yönetim ve psikoloji bilimlerinde duygu ile ilişkili kavramlara yönelik çalışma sayısının son yıllarda arttı̆̆1 görülmektedir (Vatan, 2017:46). Psikolojik belirtilerin özellikle çalışan insanlarda daha fazla gözlemlenmesinin bu ilgi üzerinde etkili olduğu ifade edilmektedir. Çalışma ortamı, örgütsel özellikler, meslektaş ve amir ilişkileri, işin kendisi, bireyin psikolojik sağlığı üzerinde rol oynayabilmekte ve bireysel davranışlar üzerinde belirleyici olabilmektedir (Carlson, Kacmar ve Williams, 2000; Hammer, Bauer ve Grandey, 2003). Ayrıca, stres, kaygı, endişe, depresyon, sosyal işlevsizlik gibi pek çok psikolojik belirti unsurunun da insan davranışları üzerinde etkili olabileceği çeşitli araştırma sonuçları ile desteklenmiştir (Frone, Russell ve Cooper, 1997; Senecal vd., 2001; Waldemström vd., 2008). Psikolojik belirtilerin gözlemlenmesinde etkili olan faktörlerden biri de özellikle iş hayatındaki bireyler için iş-aile çatışması olarak ele alınmaktadır. İşüucü demografik yapısı ile aile üyesi rollerindeki değişim, çalışan ve işveren beklentilerinin farklılaşması, bireysel refah düzeyindeki dalgalanmalar, çalışma ortamı ilişkilerindeki gerginlik iş ve aile hayatı kaynaklı çatışmaların yaşanmasında etkili olmaktadır (Hammer vd., 2005: 138). İş aile çatışması yaşayan bireyin örgütsel bağlılı̆̆1 zayıflayabilmekte, iş ortamindaki tatmin düzeyi azalmaktadır (Grandey ve Cropanzano, 1997). Ayrıca böyle bir durumda işgücü devir oranı artmakta, bilişsel yetkinlikler zayıflamakta ve üretkenlik azalmaktadır (Johnson ve Indvik, 1997). Tüm bu etmenler kişinin örgütünden uzaklaşmasına, işten ayrılma niyeti içine girmesine ve işe ya da örgüte yönelik yabancılaşma düzeyinin artmasına zemin hazırlamaktadır. Bu çalışmada, literatürden elde edilen bilgiler ışı̆̆ında iş-aile çatışmasının işe yabancılaşma üzerinde etkili olup olmadığının ortaya çıkarılması amaçlanmıştır. Ayrıca genel sağlık kavramı altında ele alınan psikolojik belirtilerin de bu etki üzerindeki rolünün ortaya çıkarılması hedeflenmiştir.

\section{Kavramsal Çerçeve}

\section{İş-Aile Çatışması}

İş-aile çatışması, çalışan bireyler için gün geçtikçe önemli hale gelen istenmeyen bir durumdur. Çalışan ve işletme beklentilerinin artması bireyler üzerindeki baskı algısını güçlendirmektedir. Bu süreçte bireyler iş hayatları ile ilgili hedefleri gerçekleştirmek için daha çok çalışmakta ve zamanlarının büyük bölümünü iş ile ilgili faaliyetlerle geçirmektedir. Günümüz çalışma ortamında bireyin iş hayatına yönelik rolleri gerçekleştirme sorumluluğu aile hayatındaki role ilişkin gerekliliklerin yürütülmesi için ihtiyaç duyulan zamanı azaltmaktadır (Gürel, 2016: 350). İş-aile çatışması da bireyin iş hayatı ve aile hayatı içerisindeki rolleri arasında denge kuramaması sonucu ortaya çıkmaktadır. Bireyin aynı anda eş, annebaba gibi birden fazla role sahip olması çatışmanın yaşanmasında etkili olmaktadır (Dubrin, 1997: 116). Çatışmaya sebep olan ana unsur, rollerin kendisinden ziyade rollerden beklenen yükümlülüklerin eş zamanlı olması ve uyumsuzluk ihtiva etmesi durumudur (Md-Sidin, Sambasivan ve İsmail, 2010: 59; Özmete ve Eker, 2012: 3). Bireyin iş ve aile hayatı arasındaki rollerinden birinin diğerine göre daha fazla belirginleşmesi iş-aile hayatı arasındaki dengeyi bozmaktadır. İş-aile hayatı arası rollere ilişkin dengesizlik çift yönlü olarak çatışmaya neden olabilmektedir (Frone, Russell ve Cooper, 1992: 67). Bireyin iş hayatına ilişkin özellikler kişinin aile hayatına müdahale etmeye başlayınca iş-aile çatışması yaşanmaktadır. Tam tersi bir durumda, bireyin aile yaşamına ilişkin özelliklerinin iş hayatına müdahale etmesi sonucunda ise aile-iş çatışması meydana gelmektedir (Greenhaus ve Beutell, 1985: 77). Çalışma süreleri, iş stresi, destekleyici olmayan yönetim, uygun olmayan çalışma koşulları, yıpratıcı liderlik gibi 
faktörler iş-aile çatışmasına; çocuk ya da yaşlı bakımı, aile üyeleri arasındaki ilişkiler ise aileiş çatışmasına neden olacak faktörlere örnek teşkil etmektedir (Michel vd., 2011: 692; Demircan ve Turunç, 2017: 49).

Bireysel rollere ilişkin çatışma; zaman temelli, gerginlik temelli ve davranış temelli olmak üzere kaynaklarına göre üç farklı şekilde gerçekleşebilmektedir (Greenhaus ve Beutell, 1985:77-81). Zaman temelli çatışmada, bireyin iş-aile hayatı rollerinden birinde harcadığ zaman diğerinden çok daha fazladır ve bu durum az zaman ayrılan rolün faaliyetlerinin gerçekleştirilmesini engellemektedir (Aktaş ve Gürkan, 2015:140). Gerginlik temelli çatışma; iş ya da aile hayatı rollerinden birinde yaşanan gerginlik, stres, kayg1, sinirlilik, depresyon gibi psikolojik belirtilerin diğer rolün aktif bir şekilde gerçekleştirilmesini etkilemesi durumudur (Parasuraman ve Simmers, 2001:556). Son olarak, davranış kaynaklı çatışmanın bir rolde sergilenen davranış ile diğer rolde sergilenmesi hedeflenen davranış arasındaki uyumsuzluk durumunda ortaya çıktığını belirtmek gerekir (Özmete ve Eker, 2012:3; Aktaş ve Gürkan, 2015:140).

İş-aile çatışması ile ilgili incelenen çalışmalarda, bireylerin iş hayatına yönelik yaşadığı çatışma sebebiyle psikolojik belirti temelli duyguların iş çıktıları ve bireysel davranışlar üzerinde istenmeyen sonuçlar doğurabileceği belirtilmektedir (Allen vd., 2000; Meyer vd., 2002; Netemeyer, Brashear-Alejandro ve Boles, 2004; Demircan ve Turunç, 2017). Ayrıca çeşitli araştırma sonuçlarına göre de iş-aile çatışmasının uzun süreli olması halinde çalışanların fiziksel ve psikolojik sağlıkları üzerinde olumsuz etkilere sebebiyet verdiği ortaya çıkarılmıştır (Cushway ve Tyler, 1996; Çarıkçı ve Çelikkol, 2009; Turunç ve Erkuş, 2010; Cullati, 2014; Sharma, Dhar ve Tyagi, 2016). Bununla birlikte, iş-aile çatışması yaşayan bireyler çatışma çözümü için işten ayrılma niyeti içine girebilmekte ya da örgütsel uzaklaşma, işe yabancilaşma gibi istenmeyen davranışlara yönelebilmektedir (Allen vd., 2000; Senecal, Vallerand ve Guay, 2001; Netemeyer, Brashear-Alejandro ve Boles, 2004; Pal ve Saksvik, 2008; Masuda vd., 2012; Erdilek-Karabay, 2015).

\section{Psikolojik Belirtiler}

Genel sağlık kavramı altında ele alınan psikolojik belirtiler, kişilerin çeşitli etmenler uyarınca yaşayabileceği ruhsal durumları ifade etmektedir (Allen vd., 2000:300). Bu çalışmada iş yaşamı kaynaklı psikolojik belirti unsurlarından kaygı, stres, depresyon ve sosyal işlevsizlik kısaca ele alınmaktadır.

Toplumda en sık rastlanan psikolojik belirtiler arasında yer alan kaygı (anksiyete bozukluğu); bireylerin fonksiyonelliğini olumsuz yönde etkileyen psikolojik bir belirti türüdür (Korkmaz, 2018:45). Kaygı, belirli bir olguya yönelik korkuyu tanımlamaktadır. Belirli bir olguya ya da duruma yönelik sıkıntı hissetme, aşırı heyecan duyma, aniden bir şey olacak gibi düşünme, kötü beklentiler, sürekli endişe hali bireyin kaygı duymasına neden olacak duygusal belirtilerdir (Karamustafalığlu ve Yumrukçal, 2011: 69). İşe yönelik kaygı ise bireyin iş ile ilgili korku ve gerginlik yaşaması durumudur. Bireyin işini yapamayacağ tamamlayamayacağı düşüncesi kaygıyı arttırmaktadır (Büyüköztürk, 1997:454). Ayrıca iş-aile çatışması, engellenme, iş yükü ve yeterli desteğin olmaması da kaygı üzerinde etkili olmaktadır (Haslam vd., 2005; Waldenström vd., 2008;). İşe yönelik kaygı; iş verimini azaltmakla birlikte dikkat ve yoğunlaşmanın düşmesine neden olur. Ayrıca kaygının iş

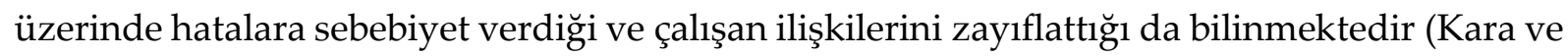
Acet, 2012; Gökçe ve Dündar, 2008). 
Diğer bir psikolojik belirti türü de strestir. Stres, kişinin beklenmedik bir durum karşısındaki tepkisi olarak ele alınmaktadır (Keser ve Güler, 2016: 296). Stres, bireyin çeşitli etmenler nedeni ile dengesinin bozulduğunu ve tekrar bu dengenin sağlanması gerekliliğine işaret eden bir göstergedir (Şahin, Güler ve Basım, 2009; Yıldız, 2017). Çalışma ortamlarının modernleşmesi sürecinde iş ve iş beklentilerinin artması çalışanlar üzerinde stres yaratabilmektedir. Ayrıca kişinin üstlendiği rollere ilişkin yaşanan çatışma da stres oluşumunu tetiklemektedir. Parker ve Decotiis (1983) uzaklaşma, yabancılaşma verimlilik kaybı ve işe gelmeme gibi problemlerin yaşanmasında iş stresinin etkili olduğunu belirtmektedir.

Depresyon ise bireydeki duygu durumu bozukluğunu ifade etmektedir (Üstün ve Bayar, 2015:385). Çökkünlük, fazla üzüntülü olma, sinirlilik, düşünce ve konuşma gibi çeşitli fizyolojik görevlere ilişkin yavaşlık ve durgunluk da depresyonu tanımlayan belirtilerdir (Türkçapar, 2011; Tanrıverdi, 2017; Temel ve Kutlu, 2019). Depresyonda olan birey belirli bir duygu durumunu olması gereken düzeyin altında ya da üstünde yaşayarak standart değerden uzaklaşmaktadır (Karamustafalığlu ve Yumrukçal, 2011: 66). Depresyon yaşayan birey işyerinde diğer çalışanlardan uzaklaşır ve işbirliği yapma hevesi ortadan kalkar. Depresyonun ilerleyen yıllarda iş yaşamı kaynaklı hastalıkların en önemlisi haline geleceği tahmin edilmektedir. Bu nedenle bireyi iş hayatı kaynaklı depresyona sokabilecek çalışma ortamı özelliklerinin belirlenmesi ve önlem alınması gerekmektedir (Başoğul ve Buldukoğlu, 2015:1).

Son olarak sosyal işlevsizlik, grup içerisinde faaliyette bulunamama, grup ile uyum sağlayamama, etrafındaki diğer kişiler ile arkadaşlık kuramama ya da çok zayıf ikili ilişkilere sahip olma durumunu tanımlamaktadır (Parker ve Asher, 1993). Sosyal işlevsizlik kısaca, sosyal olmayan hatta anti-sosyal olarak tanımlanan davranışlar içinde bulunma halidir. Clark, Gresham ve Elliot'a (1985) göre sosyal işlevsizlik, prososyal beceri eksikliğini ifade eden bir kavramdır. Sosyal işlevsiz olarak değerlendirilen kişiler yaşadığı sorunlar ile yüzleşebilme gücünden yoksundur. Ayrıca bu kişiler faaliyetlere ilişkin karar alma süreçlerinde de aktif olamamaktadır (Kalliath, O'Driscoll ve Brough, 2004: 17).

\section{Yabancılaşma}

Yabancılaşma kavramının kökeni antik çağlara kadar dayanmakta ve çeşitli dillerde farklı anlamları bulunmaktadır. Kavram, felsefe, din ve psikoloji alanındaki kuramların yanı sıra yönetim ve örgüt ile ilgili çalışmalarda da kendine özgü bir yer edinmiştir (Fettahlıŏlu, 2006: 28; Tükel, 2012: 38; Kartal, 2017: 114). Latince “Alinato" teriminden türetilen yabancilaşma kavramı bilimsel olarak ilk defa Karl Marx tarafından ele alınmıştır (Ulusoy, 2017:1; Özturan, 2018: 90). Kavram, Karl Marx tarafından endüstriyel anlamda üretim araçları ile ilişkilendirilmiş ve bireyin üretkenliğine, çalışma ortamına, diğer insanlara ve kendisine yönelik yabancılaşma tutumu olarak ifade edilmiştir (Yalçın ve Koyuncu, 2014: 87; Yüksel, 2014: 164). Bu bakış açısıyla işe yabancılaşma, iş ve birey arasındaki uyum sorunu sonucu oluşan çelişkisel durum olarak tanımlanmaktadır (Yüksel, 2014). İse yönelik beklentiler ile iş gereklerinin farklı olması bireyde hayal kırıklıklarının yaşanmasına ve pişmanlık duygularının artmasına sebep olmaktadır (Aiken ve Hage, 1966: 497). Bireyin işe yönelik beklentilerinin giderilmemesi, kişinin kendini robotik bir yapıda hayatına devam eden bir unsur olarak görmesi, örgüt içi sorunlar yabancilaşma olgusunun oluşumuna zemin hazırlamaktadır. Ayrıca iş ve aile hayatı arasındaki rol dengesizliğinden kaynaklanan çatışmanın da yabancılaşmaya yol açabilecek çevresel faktörler içinde yer aldığ belirtilmektedir (Şimşek vd., 2006: 576). 
Bireysel, mesleksel ve örgütsel kaynakları olan yabancılaşma olgusunun baş göstermesi durumunda birey ve örgüt hedefleri ile bağdaşmayan huzursuzluk ve gerginlik temelli tutum ve davranışlar ortaya çıkmaktadır (Fettahlıŏlu, 2006: 45). Motivasyon kaybı, stres, örgütsel uzaklaşma, devamsızlık, işten ayrılma niyetinin baş göstermesi, umursamazlık, geri çekilme, soyutlanma, ortam ile bütünleşememe, performans kaybı, sapma davranışlarının gözlemlenmesi yabancılaşma ile ilişkili olarak ortaya çıkabilecek davranışsal durumlardır (Seeman, 1983; Sidorkin, 2004; Erjem, 2005; Clifton, Mandzuk ve Roberts, 1994; Tutar, 2010; Ünsar ve Karahan, 2011).

Yabancılaşma olgusu farklı düzeylerde gerçekleşebilmektedir (Zhang vd., 2016: 1254). Kişinin işe yabancılaşması, örgüte yabancılaşması, kendine yabancılaşması bu kavram farklılıklarına

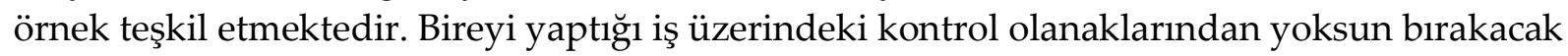
mesleksel özellikler, işe yabancılaşma olarak tanımlanmaktadır (Kanungo, 1992: 416). Kişi, yaptığı işten ve iş süreçlerinden uzaklaşıp mesleğini icra etme hevesi azalıyorsa bu durumda işe yabancılaşma baş göstermektedir (Atay ve Gerçek, 2017: 324). Örgütsel yabancılaşma ise kişinin işini değil mesleğini icra ettiği kuruma yönelik algısı nedeniyle yabancılaşma yaşaması durumudur (Yılmaz ve Sarpkaya, 2009: 323). Yönetim biçimi, psiko-sosyal çalışma koşulları, örgüt kültürü, örgütsel stres ve çatışma örgütsel yabancılaşmanın öncülleri olarak değerlendirilmektedir (Özturan, 2018: 103-108). En tehlikeli yabancllaşma türü ise bireyin kendi özünde duyduğu yabancılaşmadır (Yılmaz ve Sarpkaya, 2009: 323). Bireyin benlik yabancılaşması yaşaması durumunda kendini sosyal hayattan tamamen soyutlayarak yaşamdan uzaklaşma yönelimine girmesi muhtemeldir.

Seeman(1959) yabancılaşmayı bilimsel disiplinde ele alarak kavramı beş boyut altında incelemiştir. Bu boyutlar; güçsüzlük, anlamsızlık, kuralsızlık, yalıtılmışlık ve kendine yabancılaşmadır.

Güçsüzlük: Bireyin davranışlarının ve faaliyetlerinin istediği sonuçlara ulaştırmayacağına yönelik düşüncelerini tanımlamaktadır (Yeniçeri, 2009). Bireyin, işine yönelik faaliyetlerini ve kariyerini kendisi dışındaki etkenlerin kontrol edip yönlendireceğine yönelik tutumlarıdır (Yllmaz ve Sarpkaya, 2009: 322).

Anlamsızlık: Bireysel davranışların tahmin edilmesine fayda sağlayacak şekilsel becerilerden yoksun olma ve kararsız kalma durumudur (Yeniçeri, 2009:142). Kişinin anlamlandıramadığ durumlara ilişkin çelişki yaşaması ve uyum sağlayamamasıdır (Lindley, 1990: 27; Shepard, 1972: 166; Yilmaz ve Sarpkaya, 2009: 322; Tutar, 2010: 179; Eryılmaz ve Burgaz, 2011: 274).

Kuralsızlık (Normsuzluk): Toplumsal kurallara yönelik bağlılığın ortadan kalkmasıyla oluşan yabancılaşma boyutudur. Kuralsız bireyler, uygun olmayan ve kabul görmeyen davranışlara yönelmektedir (Brown, Higgins ve Paulsen, 2003: 3; Tutar, 2010: 180). Kişinin amaç ve hedeflerine, kabul görmüş kurallardan ziyade toplumsal olarak uygun bulunmayan ya da etik ve ahlaki kabul edilmeyen davranışlar ile daha kolay erişeceğine yönelik algısıdır (Yılmaz ve Sarpkaya, 2009: 323).

Yalıtılmışlık (Sosyal İzolasyon): Kişinin kendi isteği ile bulunduğu ortamdan uzaklaşarak sosyal ilişki kurmaktan kaçınmasıdır (Yalçın ve Koyuncu, 2014: 87). Bireyin diğer insanlar ile olan ilişkisini azaltma isteği psikolojik olabileceği gibi çevresel etmenler kaynaklı da gerçekleşebilir (Elma, 2003: 35; Eryılmaz ve Burgaz, 2011: 274). Kişi kendi isteğiyle değil de toplum tarafından kabul görmüyor hatta dışlanıyorsa izolasyon çevre kaynaklı meydana gelmektedir (Yılmaz ve Sarpkaya, 2009: 323). 
Kendine Yabancılaşma (Kendine İzolasyon): Bireyin kendi varlı̆̆ından uzaklaşma eğilimidir(Şimşek vd., 2006: 574). Kendine yabancılaşan birey yaptığ olamayan bireydir (Moç, 2018: 39).

\section{Yöntem}

\section{Araştırmanın Amacı}

$\mathrm{Bu}$ araştırmanın amacı; iş-aile çatışmasının işe yabancılaşma üzerinde etkili olup olmadığının ortaya çıkarılmasını sağlamak ve bu etkide psikolojik belirtilerin rolünü belirlemektir. Araştırma değişkenleri; iş-aile çatışması, psikolojik belirtiler ve işe yabancılaşmadır.

\section{Araştırma Modeli}

Literatür taramasında elde edilen sonuçlar doğrultusunda araştırma modeli ve hipotezi aşağıdaki gibi oluşturulmuştur (Allen vd., 2000; Meyer vd., 2002; Netemeyer, BrashearAlejandro ve Boles, 2004; Waldenström vd., 2008; Pal ve Saksvik, 2008; Çarıkçı ve Çelikkol, 2009; Masuda vd., 2012; Cullati, 2014; Sharma, Dhar ve Tyagi; 2016).

$\mathrm{H}_{1}$ :İş-aile çatışmasının işe yabancılaşma üzerindeki etkisinde psikolojik belirtilerin aracı rolü vardır.

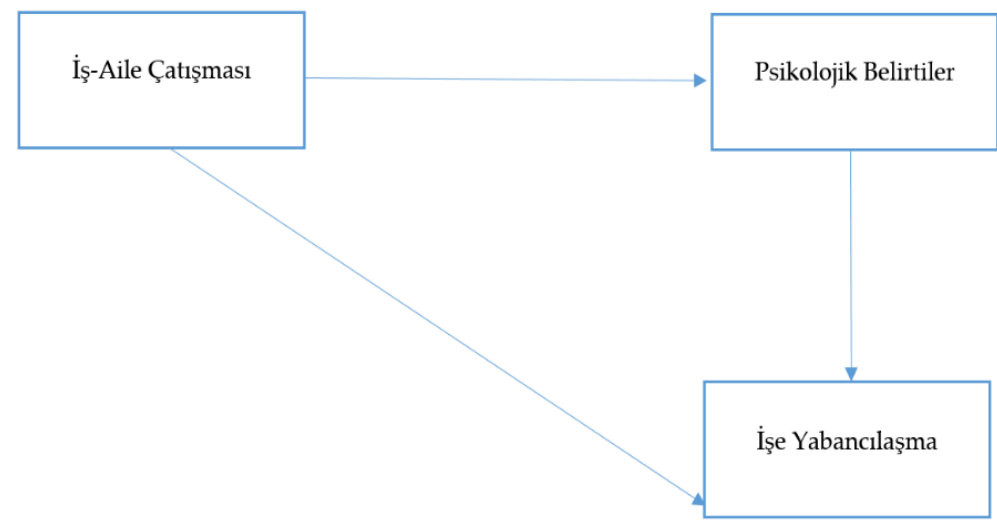

Şekil 1. Araştırma Modeli

\section{Evren ve Örneklem}

Araştırmanın ana kütlesini Türkiye'nin üç şehrinde şubesi olan özel bir lojistik işletmesinin çalışanları oluşturmaktadır. Lojistik işletmesi genel merkezinden (A şubesi) edinilen bilgiler doğrultusunda (2018 yılı çalışan sayısı 427) örneklem hesaplaması yapılmış ve 203 anketin \%95 güvenilirlik düzeyinde ana kütleyi temsil edebileceğine karar verilmiştir (Barlett vd., 2001: 46).Bu kapsamda üç şubede çalışan sayısı oranları dikkate alınarak A şubesine 150, B şubesine 100 ve $C$ şubesine 50 olmak üzere toplam 300 anket gönderilmiştir. Elde edilen anketler incelenmiş ve 247 tanesinin analizler için uygun olduğuna karar verilmiştir.

\section{Veri Toplama Araçları}

İş-Aile Çatışması Ölçeği: Netemeyer, Boles ve McMurrian (1996) tarafından geliştirilen ölçekten faydalanılmıştır. Orjinal ölçek iş-aile çatışması ve aile-iş çatışmasını ölçmek amacıyla iki boyuttan oluşmaktadır. Bu araştırmada iş-aile çatışması boyutu ele alınmış ve orjinal ölçekteki beş ifadeden faydalanılmıştır. 
Psikolojik Belirtiler: Araştırmada psikolojik belirtiler genel sağlık ölçeği kullanılarak ölçülmüştür. 1988 yılında Goldberg ve Williams tarafından geliştirilen 12 ifadeli ölçeğin Türkçe geçerlilik ve güvenilirliği Kılıç (1992) tarafından yapılmıştır. Ölçeğin kısalığı ve farklı meslek gruplarında da kullanım kolaylığına sahip olması psikolojik belirtileri ölçmek için tercih edilmesinde önem arz etmektedir. Ölçek, Sosyal İşlevsizlik ve Kayg1-Depresyon olmak üzere iki faktörden oluşmaktadır. Ölçekte, günlük faaliyetlerden keyif alma, zorluklarla başa çıkma ve benlik değerlemesi ile ilgili ifadeler bulunmaktadır.

İşe Yabancılaşma: Araştırmada Marx'ın yabancılaşma kuramı doğrultusunda Kaya ve Serçeoğlu'nun (2013) oluşturduğu Atay ve Gerçek'in (2017) kullandığ 1 altı ifade ve tek boyuttan oluşan ölçek kullanılmıştır.

\section{Verilerin Toplanması ve Analizi}

Araştırma için birincil ve ikincil veri kaynaklarından yararlanılmıştır. Araştırmanın verileri 2018 yılında toplanmıştır. Araştırmada kullanılan anket formu katılımcılara hitap edilerek yazılmış ön bilgi yazısı ile başlamaktadır. Ankete ilişkin ifadelerin değerlendirilmesi için 5'li Likert sistemi kullanılmıştır. Verilere ilişkin öncelikle normallik testleri yapılmış, araştırma değişkenlerine ilişkin çarpıklık-basıklık değerleri ve histogram eğrileri değerlendirilmiş ve verilerin normal dağılım gösterdiği saptandıktan sonra araştırma hipotezini test etmek amacıyla parametrik analizlerden yararlanılmıştır. Ayrıca araştırma modelinin test edilmesinde Baron ve Kenny'nin (1986) aracılık testi varsayımlarından faydalanılmıştır. Araştırmada yer alan ölçeklerin faktöriyel yapılarını incelemek, ölçeklerin güvenilirliğini belirlemek, değişkenler arası ilişkileri saptamak ve araştırma modelini test etmek için IBM Statistics SPSS 21.00 programı kullanılmıştır.

\section{Bulgular}

Katılımcıların verdikleri cevaplar doğrultusunda araştırma değişkenlerine ilişkin ortalamalar değerlendirildiğinde; iş-aile çatışması ortalamasının 3,46; psikolojik belirti ortalamasının 3,04; işe yabancılaşma ortalamasının 3,78 olduğu sonucuna ulaşılmıştır. Katılımcıların verdikleri cevaplara göre iş-aile çatışması, işe yabancılaşma ortalamalarının yüksek; psikolojik belirti ortalamasının diğer değişkenlere göre daha düşük düzeyde olduğunu söylemek mümkündür.

Tablo 1. Ölçeklere ilişkin Ortalama ve Standart Sapma Değerleri ve Korelasyon Katsayıları

\begin{tabular}{cccccc}
\hline & Ortalama & $\begin{array}{c}\text { Standart } \\
\text { Sapma }\end{array}$ & $\begin{array}{c}\text { İş-Aile } \\
\text { Çatışması }\end{array}$ & $\begin{array}{c}\text { Psikolojik } \\
\text { Belirtiler }\end{array}$ & $\begin{array}{c}\text { İşe } \\
\text { Yabancllaşma }\end{array}$ \\
\hline $\begin{array}{c}\text { İş-Aile } \\
\text { Çatı̧ması }\end{array}$ & 3,46 &, 891 & 1 & & $0.402^{* *}$ \\
$\begin{array}{c}\text { Psikolojik } \\
\text { Belirtiler } \\
\text { İşe }\end{array}$ & 3,04 &, 628 & $0.647^{* *}$ & 1 & \\
Yabancılaşma & 3,78 &, 464 & & $0.450^{* *}$ & 1 \\
\hline
\end{tabular}

Değişkenler arasındaki ilişkileri incelemek için Pearson Korelasyon Analizi kullanılmıştır. İşaile çatışması ile işe yabancılaşma arasında orta düzey bir korelasyon olduğu sonucuna ulaşılmıştır(r=0.402). Ayrıca psikolojik belirti durumu ile işe yabancılaşma arasında da orta düzey bir ilişki vardır ( $\mathrm{r}=0.450$ ). İş-aile çatışması ve psikolojik belirti arasında da orta düzey bir 
ilişki olduğu tespit edilmiştir(r=0.647).Değişkenler arası ilişkilerin pozitif yönde ve istatistiksel olarak anlamlı olduğunu da belirtmek gerekmektedir $(p<0.05)$. Araştırmada kullanılan ölçeklere ilişkin güvenilirlik analizleri yapılmış ve iç tutarlılık katsayıları (Cronbach Alpha$\alpha$ ) incelenmiştir. İş-aile çatışması ölçeği iç tutarlılık katsayısı 0.904, psikolojik belirtiler iç tutarlılık katsayısı 0.813 , işe yabancılaşma iç tutarlılık katsayısı $0.864^{\prime}$ tür. Ölçeklerin güvenilir olduğuna karar verilmiştir $(\alpha>0.70)$.

Araştırmada kullanılan ölçeklerin yapı geçerliliğini test etmek amacıyla yapılan faktör analiz sonuçları Tablo 2'de yer almaktadır. Tablo 2' de yer alan verilere göre kullanılan ölçeklerin faktör analizi yapabilmek için uygun olduğunu söylemek mümkündür. 5 ifadeden oluşan işaile çatışması ölçeği tek boyut altında toplanmıştır. Ölçeğe ilişkin açıklayıcılık \%73.020'dir. Psikolojik belirtiler 12 ifade ve iki boyuttan oluşan genel sağlık anketi ile ölçülmüş ve ölçek iki faktör altında toplanmıştır. Ölçeğin kümülatif açıklayıcılı̆̆ $1 \% 79.882$ 'dir. Son olarak 6 ifade ile ölçülen işe yabancılaşma ölçeğinin de tek boyut altında açıklayıcılığının \%64.425 olduğu sonucuna ulaşılmıştır. Ölçeklere ilişkin faktör yükleri incelendiğinde ise iş-aile çatışması ölçeğine ilişkin faktör yükleri 0.773-0.936 aralığında; psikolojik belirtilere ilişkin faktör yükleri birinci faktör(sosyal işlevsizlik) için 0.662-0.919, ikinci faktör(kayg1-depresyon) için 0.512-0.787 aralığında, işe yabanclaşma ölçeğine ilişkin faktör yükleri 0.502-0.892 aralığında dağılım göstermiştir.

Tablo 2. Faktör Analizi Sonuçları

\begin{tabular}{cccc}
\hline & $\begin{array}{c}\text { İş-Aile } \\
\text { Çatışması }\end{array}$ & $\begin{array}{c}\text { Psikolojik } \\
\text { Belirtiler }\end{array}$ & İşe Yabancılaşma \\
\hline KMO Değeri &, 784 &, 721 &, 796 \\
Bartlett's Test df Değeri & 10 & 15 &, 000 \\
Kovaryans Matrisi En &, 000 &, 513 &, 590 \\
Küçük Diagnol Değeri &, 597 & & \\
Kümülatif Açıklayıcılık & $\% 73,020$ & $\% 79,882$ & $\% 64,425$ \\
& & & \\
\hline
\end{tabular}

Araştırma hipotezinin test edilmesi amacıyla Hiyerarşik Regresyon Analizi yapılmıştır. Bu doğrultuda Baron ve Kenny'nin (1986:1176) uyguladığı adımlardan faydalanılmıştır. Tablo 3'de gösterildiği gibi birinci basamak regresyon analizinde katılımcıların iş-aile çatışması algısının işe yabancılaşma üzerindeki etkisi incelenmiş ve iş-aile çatışmasının işe yabancılaşma üzerinde istatistiksel olarak anlamlı bir etkisinin olduğu saptanmıştır.(Model 1, p=0,000<0,05). İş-aile çatışmasının işe yabancılaşma üzerindeki pozitif etki katsayısı 0.402 'dir( $\beta$ ). İşe yabancılaşmadaki değişimin \% 16.1'lik bir bölümü iş aile çatışması tarafından açıklanmaktadır. İkinci basamak regresyon analizinde ise iş-aile çatışmasının psikolojik belirtiler üzerindeki etkisi incelenmiş ve iş-aile çatışmasının psikolojik belirtiler üzerinde anlamlı bir etkisi olduğu tespit edilmiştir. (Model 2, p=0,000<0,05) Aracılık testinin son aşamasında ise iş-aile çatışması ve psikolojik belirtilerin birlikte işe yabancılaşma üzerindeki etkisi analiz edilmiştir. Üçüncü modele göre iş-aile çatışmasının işe yabancılaşma üzerindeki etkisi hala anlamlıdır (Model 3, p=0,022 <0,05). İş-aile çatışması ve psikolojik belirtiler birlikte işe yabancılaşma üzerindeki değişimin \%21.6'sını açıklamaktadır. Bu modelde iş-aile çatışmasının pozitif etki katsayısı 0.190; psikolojik belirtilerin pozitif etki katsayısı 0.327 'dir. 
Aracılık testinin son basamağında iş-aile çatışmasına ilişkin anlamlılık değerinin 0.022 çıkması ve bu durumun modelin anlamlılı̆̆ını korumaya devam ettirmesi sonucunda değişkenler arasında tam aracılık etkisinden söz edilemez. Ancak birinci basamakta iş-aile çatışmasının işe yabancılaşma üzerindeki pozitif etki katsayısı yani Beta ( $\beta$ ) 0.402 iken; üçüncü basamaktaki psikolojik belirtilerin modele dâhil olmasıyla birlikte bu değer $0,190(\beta)^{\prime}$ a düşmüsstür. $\mathrm{Bu}$ sonuçlara göre psikolojik belirtilerin kısmi aracı role sahip olabileceğini söylemek mümkündür.

Tablo 3. Birinci, İkinci ve Üçüncü Basamak Regresyon Analizi Sonuçları

Hipotez 1: Birinci Basamak Regresyon Analizi Sonuçları

Bağımlı Değişken: İşe Yabancılaşma (Model 1)

\begin{tabular}{llll}
\hline Bağımsız Değişken: & & & \\
İş-Aile Çatışması & $\underline{B e t a}$ & $\underline{t}$ & $\underline{0}$ \\
& 0.402 & 6.189 & \\
& & F: & $p$ \\
& $\mathrm{R}^{2}:$ & 38.301 & 0.000 \\
\hline
\end{tabular}

Hipotez 1: İkinci Basamak Regresyon Analizi Sonuçları

Bağımlı Değişken: Psikolojik Belirtiler (Model 2)

Bağımsız Değişken:

İş-Aile çatışması

$\underline{B e t a}$

0.647

$\underline{t} \quad \underline{p}$

$11.983 \quad 0.000$

$\mathrm{R}^{2}$ :

F:

0.419

143.589

$p$

0.000

\begin{tabular}{|c|c|c|c|}
\hline \multicolumn{4}{|c|}{$\begin{array}{l}\text { Hipotez 1: Üçüncü Basamak Regresyon Analizi Sonuçları } \\
\text { Bağımlı Değişken: İşe Yabancılaşma (Model 3) }\end{array}$} \\
\hline \multicolumn{4}{|c|}{ Bağımsız } \\
\hline Değişkenler: & Beta & $\underline{t}$ & $p$ \\
\hline İş-Aile Çatışması & 0.190 & 2.315 & 0.022 \\
\hline \multicolumn{4}{|l|}{ Psikolojik Belirtiler } \\
\hline & 0.327 & 3.976 & 0.000 \\
\hline & $\begin{array}{l}\text { Düzeltilmiş R²: } \\
0.216\end{array}$ & $\begin{array}{l}\text { F: } \\
28.480\end{array}$ & $\begin{array}{l}p \\
0.000\end{array}$ \\
\hline
\end{tabular}

Kısmi aracılık rolünün anlamlı olup olmadığının tespiti için çevrim içi Sobel Test İstatistiği Hesaplama programından faydalanılmıştır. Sobel Test istatistiklerinin hesaplanması için iş aile çatışmasının psikolojik belirti düzeyi üzerindeki etkisinde standardize olmayan regresyon katsayısı a, bu yöndeki standart hata sa olarak ele alınmaktadır. Bu aşamada regresyon analizi hesaplamasında elde edilen katsayılar tablosundaki standardize olmayan değerlerden faydalanılmaktadır. Aynı şekilde aracı değişken olan psikolojik belirtiler ve bağımlı değişken olan işe yabancılaşma ilişkisindeki standardize olmamış regresyon katsayısı b, bu yöndeki standart hata ise sb olarak ele alınmaktadır (Gürbüz ve Bekmezci, 2012:201). Yapılan analizler sonucunda test istatistik değerlerinin 6 ve üzerinde çıkması $(Z=6.09,6.07,6.10 ; p<, 01) \mathrm{k} 1 \mathrm{smi}$ aracılığının istatistiksel olarak anlamlı olduğunu ortaya çıkarmaktadır. 
Tablo 4. Sobel Test İstatistiği Sonuçları

\begin{tabular}{c|l|c|c|c}
\hline Veriler & & Test İstatistiği & Standart Hata & $p$-Değeri \\
\cline { 1 - 4 } a:0.457 & Sobel: & 6.09087 & 0.0249 & 0.000 \\
b:0.332 & Aroian: & 6.07527 & 0.0249 & 0.000 \\
Sa: 0.038 & Goodman: & 6.10658 & 0.0248 & 0.000 \\
Sb: 0.047 & & & &
\end{tabular}

\section{Tartışma ve Sonuç}

Allen ve arkadaşları (2000) iş aile çatışmasının işten ayrılma, devamsızlık, uzaklaşma gibi sonuçlarının yanı sıra stres ve depresyon başta olmak üzere çalışanların ruhsal durumlarını etkileyecek psikolojik belirtilerin oluşumunu da etkilediğini belirtilmektedir. Feldman ve arkadaşları (1999) ile Gunthert, Cohen ve Armeli (1999) ise iş hayatı kaynaklı çatışma türlerinin kaygı, stres ve depresyon ile pozitif ilişkiye sahip olduğunu ifade etmektedirler. Ayrıca Kinnunen ve Mauno (1998) ile Major, Klein ve Ehrhart (2002) iş-aile çatışması ve psikolojik belirtilerin ilişkili olduğunu saptamışlardır. Hammer ve arkadaşları da (2005) işaile çatışmasının istenmeyen iş çıktıları ile ilişkili olduğunu vurgulamış ve yaptıkları araştırmada iş-aile çatışmasının psikolojik belirti unsurları ile pozitif ilişkiye sahip olduğu sonucuna ulaşmışlardır. Frone (2000) ise çalışmasında iş-aile çatışması yaşayan kişilerin psikolojik rahatsızlıklara yatkınlıklarının, iş aile çatışması yaşamayanlara göre 3.1 kat daha fazla olduğunu ortaya çıkarmıştır. Johnson ve Indvik (1997) depresyon başta olmak üzere çeşitli psikolojik belirti türlerinin üretkenlik ve performans üzerinde azalışa; işgücü devriişten uzaklaşma ve devamsızlık üzerinde ise artışı sebep olduğunu belirtmektedir. Ayrıca, Sharma, Dhar ve Tyagi (2016) ile Waldenström ve arkadaşları (2008) da çatışma, psikolojik unsurlar ve olumsuz iş davranışları arasındaki ilişkileri incelemişlerdir.

$\mathrm{Bu}$ araştırma, lojistik işletmesi çalışanlarının iş-aile çatışması algısının işe yabancılaşma üzerindeki etkisinde psikolojik belirtilerin rolünün ortaya çıkarılmasını amaçlanmıştır. Yapılan parametrik analizler neticesinde; katılımcıların iş-aile çatışması, psikolojik belirtiler ve işe yabancılaşma algılarının orta değerin üzerinde olduğu ancak psikolojik belirtilerin diğer değişkenlerden daha düşük bir ortalamaya sahip olduğu sonucuna ulaşılmıştır. Araştırma bulgularından hareketle, işe yabanclaşma üzerindeki değişimin \%16.1'lik bir kısmının iş-aile çatışması tarafından açıklandığı ve iş-aile çatışmasının işe yabancılaşma üzerindeki pozitif etki katsayısının 0,402 olduğu ortaya çıkarılmıştır. Yapılan Hiyerarşik Regresyon Analizleri sonucunda ise psikolojik belirtilerin iş-aile çatışması ve işe yabancılaşma ilişkisinde kısmi aracı role sahip olduğu saptanmış ve bu rolün anlamlılığı Sobel Testi sonuçları ile güçlendirilmiştir. Kısaca, araştırma hipotezinin kısmen kabul edildiğini söylemek mümkündür.

Rhodes, (2004) stres, depresyon, anksiyete gibi pek çok ruhsal belirtinin işletmelere maliyetinin çok yüksek olduğunu belirtmektedir. İş gücü devri maliyetleri, yeni işe alma maliyetleri, eğitim ve oryantasyon maliyetleri işletmelerin finansal yapıları üzerinde etkili olabilmektedir. Bu nedenle çalışanların ruhsal durumları üzerinde olumsuzluk yaratacak unsurların belirlenmesi ve bu unsurların çalışanları devamsızlık, yabancılaşma, uzaklaşma, işten ayrılma gibi istenmeyen davranışlara yönlendirmesini engelleyecek stratejiler geliştirilerek kişilerin ruhsal olarak da sağlıklarının devamlılığının sağlanması gerekmektedir. 
Toplum sağlığının arttırılması için psikolojik sağlığın korunması önem arz etmektedir. İş yaşamı kaynaklı psikolojik belirti düzeyini azaltmak için belirli aralıklarda tarama testleri yapılmalı, iş rotasyonu, ücretli-ücretsiz dinlenme olanakları, işyerinde psikolog desteği gibi koruyucu önlemler alınmalıdır. İlerleyen araştırmalarda psikotizm, somatizasyon, kişiler arası duyarlılık gibi alt belirti gruplarını da inceleyen ölçeklerin kullanıldığı çalışmaların yapılması iş hayatının insan sağlığı ve bireysel davranışları üzerindeki etkilerinin daha detaylı bir şekilde gözlemlenmesine katkı sağlayacaktır. Ayrıca, ilerleyen araştırmalarda demografik değişkenlerin de incelendiği farklı örneklem grupları üzerinde benzer araştırmaların tekrar edilmesi daha detaylı sonuçlar ortaya çıkaracaktır. Son olarak araştırma, tek bir lojistik işletmesinin üç farklı şubesinde yapılmıştır. Birden fazla işletmeyi kapsayacak şekilde yapılacak çalışmalar ile bulguların genellenebilmesi söz konusu olacaktır. 


\section{Kaynakça}

Aiken, M., \& Hage, J. (1966). Organizational alienation: A comparative analysis. American Sociological Review, 31(4), 497-507.

Aktaş, H., \& Gürkan, G. Ç. (2015). İş-aile ve aile-iş çatışması ile bireysel performans etkileşiminde mesleki bağlılığın aracı rolü: Hemşireler üzerinde bir araştırma. Doğuş Üniversitesi Dergisi, 16(2), 139-154.

Allen, T. D., Herst, D. E., Bruck, C. S., \& Sutton, M. (2000). Consequences associated with workto-family conflict: a review and agenda for future research. Journal of occupational health psychology, 5(2), 278-308.

Atay, S. E., \& Gerçek, M. (2017). Algılanan Rol Belirsizliğinin İşe Yabancılaşma Üzerindeki Etkisinin ve Demografik Değişkenlere Göre Farklılıklarının İncelenmesi. Ordu Üniversitesi Sosyal Bilimler Araştırmaları Dergisi, 7(2), 321-332.

Barlett, J. E., Kotrlik, J. W., \& Higgins, C. C. (2001). Organizational research: Determining appropriate sample size in survey research. Information technology, learning, and performance journal, 19(1),43-50.

Baron, R. M., \& Kenny, D. A. (1986). The moderator-mediator variable distinction in social psychological research: Conceptual, strategic, and statistical considerations. Journal of personality and social psychology, 51(6), 1173-1182.

Başoğul, C., \& Buldukoğlu, K. (2015). Depresif bozukluklarda psikososyal girişimler. Psikiyatride Güncel Yaklaşımlar, 7(1), 1-15.

Brough, P., Kalliath, T. J., \& O'Driscoll, M. P. (2008). Work-family conflict and facilitation: Achieving work-family balance. A.I.Glendon et al, (Ed) Advances in Organisational Psychology (73-88). Bowen Hills, Qld: Australian Academic Press.

Brown, M.R., Higgins, K., \& Paulsen, K. (2003). Adolescent alienation: what is it and what can educators do about it? Intervention in School and Clinic, 39 (1), 3-9.

Büyüköztürk, Ş. (1997). Araştırmaya yönelik kaygı ölçeğinin geliştirilmesi. Kuram ve Uygulamada Eğitim Yönetimi, 12(12), 453-464.

Carlson, D. S., Kacmar, K. M., \& Williams, L. J. (2000). Construction and initial validation of a multidimensional measure of work-family conflict. Journal of Vocational behavior, 56(2), 249276.

Clark, L., Gresham, F. M., \& Elliott, S. N. (1985). Development and validation of a social skills assessment measure: The TROSS-C. Journal of Psychoeducational Assessment, 3(4), 347-356.

Clifton, R. A., Mandzuk, D., \& Roberts, L. W. (1994). The alienation of undergraduate education students: A case study of a Canadian university. Journal of Education for Teaching, 20(2), 179-192.

Cullati, S. (2014). The influence of work-family conflict trajectories on self-rated health trajectories in Switzerland: A life course approach. Social Science \& Medicine, 113, 23-33.

Cushway, D., \& Tyler, P. (1996). Stress in clinical psychologists. International Journal of Social Psychiatry, 42(2), 141-149. 
Çarıkçı, İ. H., \& Çelikkol, Ö. (2009). İş-Aile Çatışmasının Örgütsel Bağlılık Ve İşten Ayrılma Niyetine Etkisi. Süleyman Demirel Üniversitesi Sosyal Bilimler Enstitüsü Dergisi, (9), 153-170.

Demircan, P., \& Turunç, Ö. (2017). İş-Aile Çatışması-Duygusal Emek İlişkisinde Lider Desteğinin Rolü: Eğitim Üzerine Bir Araştırma. İstanbul Gelişim Üniversitesi Sosyal Bilimler Dergisi, 4(1), 41-76.

Dubrin, A. J. (1997). Fundamentals of organizational behaviour: An applied approach. Cincinnati: South-Western College Press.

Elma, C. (2003). Illköğretim okulu öğretmenlerinin işe yabancılaşması (Doktora tezi, Ankara Üniversitesi, Ankara). Erişim adresi: http://tez2.yok.gov.tr/

Erdilek Karabay, M. (2015). Sağlık personelinin iş stresi, iş-aile çatışması ve iş-aile-hayat tatminlerine yönelik algılarının işten ayrılma niyeti üzerindeki etkilerinin belirlenmesi üzerine bir araştırma. Yönetim Bilimleri Dergisi,13(26),113-134.

Erjem, Y. (2005). Eğitimde Yabancılaşma Olgusu ve Öğretmen: Lise Öğretmenleri Üzerine Sosyolojik Bir Araştırma. Türk Eğitim Bilimleri Dergisi, 3(4), 395-417.

Eryılmaz, A., \& Burgaz, B. (2011). Özel ve resmi lise öğretmenlerinin örgütsel yabancılaşma düzeyleri. Ĕ̈itim ve Bilim, 36, 271-286.

Feldman, P. J., Cohen, S., Lepore, S. J., Matthews, K. A., Kamarck, T. W., \& Marsland, A. L. (1999). Negative emotions and acute physiological responses to stress. Annals of Behavioral Medicine, 21(3), 216-222.

Fettahlığlu, T. (2006). Örgütlerde yabancılaşmanın yönetimi: Kahramanmaraş özel işletme ve kamu kuruluşlarında karşılaştırmalı bir araştırma (Yüksek Lisans tezi, Sütçü İmam Üniversitesi Kahramanmaraş). Erişim adresi: http://tez2.yok.gov.tr/

Frone, M. R. (2000). Work-family conflict and employee psychiatric disorders: The national comorbidity survey. Journal of Applied psychology, 85(6), 888-895.

Frone, M. R., Russell, M., \& Cooper, M. L. (1992). Antecedents and outcomes of work-family conflict: testing a model of the work-family interface. Journal of applied psychology, 77(1), 6578 .

Gokce, T., \& Dundar, C. (2008). The frequency of exposing to violence and its effects on state and trait anxiety levels among the doctors and nurses working in Samsun Psychiatry Hospital. Journal of Inonu University Medical Faculty, 15, 25-28.

Goldberg D.P., \& Williams, P. (1988). A User's Guide to the General Health Questionnaire. Windsor: NFER/Nelson.

Greenhaus, J. H., \& Beutell, N. J. (1985). Sources of conflict between work and family roles. Academy of management review, 10(1), 76-88.

Gunthert, K. C., Cohen, L. H., \& Armeli, S. (1999). The role of neuroticism in daily stress and coping. Journal of personality and social psychology, 77(5), 1087-1100.

Gürbüz, S., \& Bekmezci, M. (2012). İnsan kaynakları yönetimi uygulamalarının bilgi işçilerinin işten ayrılma niyetine etkisinde duygusal bağlılı̆̆ın aracılık ve düzenleyicilik rolü. İstanbul Üniversitesi İşletme Fakültesi Dergisi, 41(2), 189-213. 
Gürel, E. B. (2016). Duygusal tükenmişlik, iş stresi ve işe bağlılığın iş-aile çatışması üzerindeki etkisi: Amprik bir araştırma. Dumlupınar Üniversitesi Sosyal Bilimler Dergisi, 48, 349-364.

Hammer, L. B., Bauer, T. N., \& Grandey, A. A. (2003). Work-family conflict and work-related withdrawal behaviors. Journal of Business and Psychology, 17(3), 419-436.

Hammer, L. B., Cullen, J. C., Neal, M. B., Sinclair, R. R., \& Shafiro, M. V. (2005). The longitudinal effects of work-family conflict and positive spillover on depressive symptoms among dual-earner couples. Journal of occupational health psychology, 10(2), 138-154.

Haslam, C., Atkinson, S., Brown, S. S., \& Haslam, R. A. (2005). Anxiety and depression in the workplace: effects on the individual and organisation (a focus group investigation). Journal of affective disorders, 88(2), 209-215.

İşçan, Ö. F., \& Moç, T. (2018). Çalışanların Presenteizm (İşte Sözde Var Olma) Davranışlarının İşe Yabancılaşmalarına Etkisi: Bir Kamu Kurumu Örneği. Işsletme Araştırmaları Dergisi, 10(3), 379-402.

Johnson, P. R., \& Indvik, J. (1997). The scourge of the workplace: depression at work. Journal of workplace learning, 9(1), 12-16.

Kalliath, T. J., O'Driscoll, M. P., \& Brough, P. (2004). A confirmatory factor analysis of the General Health Questionnaire-12. Stress and Health: Journal of the International Society for the Investigation of Stress, 20(1), 11-20.

Kanungo, R. N. (1992). Alienation and empowerment: Some ethical imperatives in business. Journal of Business Ethics, 11(5-6), 413-422.

Kara, H., \& Acet, M. (2012). Investigation effect of the state anxiety level of sports managers on automatic thoughts. E-Journal of New World Sciences Academy, 7(4), 244-258.

Karamustafalıŏ̆lu, O., \& Yumrukçal, H. (2011). Depresyon ve anksiyete bozuklukları. Şişli Etfal Hastanesi Tıp Bülteni, 45(2), 65-74.

Kartal, N. (2017). Sağlık Çalışanlarında İşe Cezbolma, İşe Yabancılaşma ve Performans Arasındaki İlişkinin Değerlendirilmesi (Yüksek Lisans tezi, Hacettepe Üniversitesi, Ankara). Erişim adresi: http://tez2.yok.gov.tr/

Kaya, U., \& Serçeoğlu, N. (2013). Duygu İşçilerinde İşe Yabancilaşma: Hizmet Sektöründe Bir Araştırma. Calisma ve Toplum, 36(1),311-345.

Keser, A. Ve Güler, K.G.(2016). Çalışma Psikolojisi. Umuttepe Yayınları

Kılıç, C. (1992). Genel sağlık anketi: Güvenilirlik ve geçerlilik çalışması (Uzmanlık tezi, Hacettepe Üniversitesi Tıp Fakültesi, Ankara).

Kinnunen, U., \& Mauno, S. (1998). Antecedents and outcomes of work-family conflict among employed women and men in Finland. Human Relations, 51(2), 157-177.

Korkmaz, B. (2018). Öz-Duyarlık: Psikolojik Belirtiler ile İlişkisi ve Psikoterapide Kullanımı. Psikiyatride Güncel Yaklaşımlar, 10(1), 40-58.

Lindley, D. A. (1990). For teachers of the alienated: Three defenses against despair. The English Journal, 79(6), 26-31.

Major, V. S., Klein, K. J., \& Ehrhart, M. G. (2002). Work time, work interference with family, and psychological distress. Journal of applied psychology, 87(3), 427-436. 
Masuda, A. D., Poelmans, S. A., Allen, T. D., Spector, P. E., Lapierre, L. M., Cooper, C. L., ... \& $\mathrm{Lu}, \mathrm{L}$. (2012). Flexible work arrangements availability and their relationship with work-tofamily conflict, job satisfaction, and turnover intentions: A comparison of three country clusters. Applied psychology, 61(1), 1-29.

Md-Sidin, S., Sambasivan, M., \& Ismail, I. (2010). Relationship between work-family conflict and quality of life: An investigation into the role of social support. Journal of Managerial Psychology, 25(1), 58-81.

Meyer, J. P., Stanley, D. J., Herscovitch, L., \& Topolnytsky, L. (2002). Affective, continuance, and normative commitment to the organization: A meta-analysis of antecedents, correlates, and consequences. Journal of vocational behavior, 61(1), 20-52.

Michel, J. S., Kotrba, L. M., Mitchelson, J. K., Clark, M. A., \& Baltes, B. B. (2011), Antecedents of work-family conflict: A meta-analytic review. Journal of organizational behavior, 32(5), 689725 .

Moç, T. (2018). Örgütsel Adalet Algısının Çalışanların Işste Yabancılaşmaya Etkisinde Tükenmişliğin ve Presenteizmin Rolü (Doktora tezi, Atatürk Üniversitesi, Erzurum). Erişim adresi: http://tez2.yok.gov.tr/

Netemeyer, R. G., Boles, J., \& Mcmurrian, R. (1996). Development and Validation of WorkFamily Conflict and Family-Work Conflict Scales. Journal of Applied Psychology, 81, 400-410.

Netemeyer, R. G., Brashear-Alejandro, T., \& Boles, J. S. (2004). A cross-national model of jobrelated outcomes of work role and family role variables: A retail sales context. Journal of the Academy of Marketing Science, 32(1), 49-60.

Özmete, E., \& Eker, I. (2012). İş-Aile Yaşamı Çatışması ve Roller: Kamu Sektörü Örneğinde Bir Değerlendirme. Çalışma İlişkileri Dergisi, 3(2), 1-23.

Özturan, M. (2018). Yöneticilerin duygusal zekâ düzeylerinin, yönetim tarzları ve örgütsel yabancılaşma duyguları üzerindeki etkisinin incelenmesi (Doktora tezi, İstanbul Ticaret Üniversitesi, İstanbul). Erişim adresi: http://tez2.yok.gov.tr/

Pal, S., \& Saksvik, P. Ø. (2008). Work-family conflict and psychosocial work environment stressors as predictors of job stress in a cross-cultural study. International Journal of Stress Management, 15(1), 22-42.

Parasuraman, S., \& Simmers, C. A. (2001). Type of employment, work-family conflict and well-being: a comparative study. Journal of Organizational Behavior, 22(5), 551-568.

Parker, D.E. ve Decotiis, T.A. (1983). Organizational Determinants of Job Stress. Organızatıonal Behavior and Human Performance, 32, 160-177.

Parker, J. G. \& Asher, S. R. (1993). Friends and friendship quality in middle childhood: Links with peer group acceptance and feelings of loneliness and social dissatisfaction. Developmental Psychology, 29(4), 611-621.

Rhodes, A. C. (2004). Effect of conflict management styles on stress level of correctional officers (Doctoral dissertation, Alliant International University, San Diego).

Seeman, M. (1959). On the meaning of alienation. American sociological review,24(6), 783-791. 
Seeman, M. (1983), Alienation Motifs in Contemporary Theorizing: The Hidden Continuity of the Classic Themes. Social Psychology Quarterly, 46(3), 171-184.

Senécal, C., Vallerand, R. J., \& Guay, F. (2001). Antecedents and outcomes of work-family conflict: Toward a motivational model. Personality and Social Psychology Bulletin, 27(2), 176186.

Sharma, J., Dhar, R. L., \& Tyagi, A. (2016). Stress as a mediator between work-family conflict and psychological health among the nursing staff: Moderating role of emotional intelligence. Applied Nursing Research, 30, 268-275.

Shepard, J. M. (1972). Alienation as A Process: Work as A Case in Point. The Sociological Quarterly, 13(2), 161-173.

Sidorkin, A. M. (2004). In the event of learning: Alienation and participative thinking in education. Educational Theory, 54(3), 251-262.

Şahin, N. H., Güler, M., \& Basım, H. N. (2009). A tipi kişilik örüntüsünde bilişsel ve duygusal zekânın stresle başa çıkma ve stres belirtileri ile ilişkisi. Türk Psikiyatri Dergisi, 20(3), 243254.

Şimşek, M. Ş., Çelik, A., Akgemci, T., \& Fettahlığlu, T. (2006). Örgütlerde yabancılaşmanın yönetimi araştırması. Selçuk Üniversitesi Sosyal Bilimler Enstitüsü Dergisi, 15, 569-587.

Tanriverdi, S.(2017). Öğrencilerinin Depresyon Düzeylerini Yordayan Değişkenlerin Belirlenmesi: Multinominal Lojistik Regresyon Analizi. Yüzüncü Yıl Üniversitesi Eğitim Fakültesi Dergisi, 14(1), 1517-1543.

Temel, M., \& Kutlu, F. Y.(2019). Functional Health Pattern Model Based Care Plan for a Depression Diagnosed Patient. Florence Nightingale Hemşirelik Dergisi, 27(1), 91-103.

Tezcan, S., \& Aslan, D. (2000). Ankara'da Çeşitli Meslek Gruplarında Genel Ruhsal Sağlık Durumunun Değerlendirilmesi. Kriz Dergisi, 9(1),1-8.

Turunç, Ö., \& Erkuş, A. (2010). İş-Aile Yaşam Çatışmasının İş Tatmini Ve Örgütsel Bağlılık Üzerine Etkileri: İş Stresinin Aracılık Rolü. Sosyal Ekonomik Araştırmalar Dergisi, 10(19), 415440 .

Tutar, H. (2010), İşgören Yabancılaşması Ve Örgütsel Sağlık İlişkisi: Bankacılık Sektöründe Bir Uygulama. Ankara Üniversitesi SBF Dergisi, 65(1), 175-204.

Tükel, İ. (2012). Modern Örgütlerde Yabancılaşma Ve Kafka'nın “Dönüşüm” Romanının Bu Bağlamda Analizi. Dokuz Eylül Üniversitesi Edebiyat Fakültesi Dergisi, 1(2), 34-50.

Türkçapar, M.H. (2011). Dirençli depresyon tedavisinde bilişsel davranışçı yaklașım. Psikiyatride Güncel, 1(3), 240-250.

Ulusoy, H. (2017). Sanayi Örgütü işçileri ve işe yabancılaşma. Ankara Üniversitesi Dil ve TarihCoğrafya Fakültesi Dergisi, 32(1-2).77-84.

Ünsar, A. S., \& Karahan, D. (2011). Yabancılaşmanın İşten Ayrılma Eğilimine Etkisini Belirlemeye Yönelik Bir Alan Araştırması. Sosyal Ekonomik Araştırmalar Dergisi, (21), 361378. 
Üstün, A., \& Bayar, A. (2015). Üniversite öğrencilerinin depresyon, anksiyete ve stres düzeylerinin çeşitli değişkenlere göre incelenmesi. Eğitim ve Öğretim Araştırmaları Dergisi, 4(1), 384-390.

Vatan, S. (2017). Duygular ve Psikolojik Belirtiler Arasındaki İlişkiler. Psikiyatride Güncel Yaklaşımlar, 9(1), 45-62.

Waldenström, K., Ahlberg, G., Bergman, P. U., Forsell, Y., Stoetzer, U., Waldenström, M., \& Lundberg, I. (2008). Externally assessed psychosocial work characteristics and diagnoses of anxiety and depression. Occupational and Environmental Medicine, 65(2), 90-96.

Yalçın, İ., \& Koyuncu, S. C. (2014). Örgütsel Yabancılaşma Olgusunun İş Tatmini Üzerine Etkisi: Niğde İlinde Bir Araştırma. Karamanoğlu Mehmetbey Üniversitesi Sosyal ve Ekonomik Araştırmalar Dergisi, 26, 86-94.

Yeniçeri, Özcan (2009). Örgütlerde Çatışma Ve Yabancılaşma Yönetimi. IQ Kültür Sanat Yayıncilık, İstanbul.

Yıldız, M. (2017). Banka çalışanlarında stres algısı ve ruhsal durum arasındaki ilişkinin araştırılması ( Yüksek Lisans tezi, Işı1k Üniversitesi, İstanbul). Erişim adresi: http://tez2.yok.gov.tr/

Yılmaz, S., \& Sarpkaya, P. (2009). Eğitim örgütlerinde yabancılaşma ve yönetimi. Uluslararası Insan Bilimleri Dergisi, 6(2), 314-333.

Yüksel, H. (2014). Yabancılaşma Kavramı Paralelinde Emeğin Yabancılaşması ve Sonuçları. Abant İzzet Baysal Üniversitesi Sosyal Bilimler Enstitüsü Dergisi, 14(2), 159-188.

Zhang, G., Chan, A., Zhong, J., \& Yu, X. (2016), Creativity and social alienation: The costs of being creative. The International Journal of Human Resource Management, 27(12), 1252-1276. 